\title{
Fornemmelse og oppmerksomhet - artikulasjon og stemme Et kroppslig perspektiv på formidling
}

\section{Af Knut Oterholm og Kjell Ivar Skjerdingstad}

\begin{abstract}
Intensjonen med artikkelen er å bidra til utviklingen av formidlingsbegrepet gjennom å forankre det $i$ en modell av kroppslige bevissthetsmodi. Med utgangspunkt i fenomenologisk teori og studier i konkrete formidlingspraksiser, skisseres et begrep om formidling som et samspill mellom fornemmelse, oppmerksomhet, artikulasjon og stemme som alle forholder seg til omgivelsene kroppen er situert $i$.
\end{abstract}

Denne optikken skal kunne anvendes for analyse av formidlingspraksiser på tvers av konkrete mediale former.
Knut Oterholm, høgskolelektor, cand. philol. Høgskolen i Osloog Akershus (knut.oterholm@hioa.no) Kjell Ivar Skjerdingstad, førsteamanuensis, dr. art. Høgskolen i Oslo og Akershus (kjell-ivar.skjerdingstad@hioa.no)
"Tvånget att komma fram til något dödar omedelbart uppmärksamheten"

(Engdahl, 1988 s. 15)

\section{Innledning}

"Solveig tenkte på hvordan beskrivelsene i boka var så tilsynelatende riktige, presise og konkrete, men hvordan det likevel ikke kjentes ekte. Det var ikke sant. Hun kjente det som en søyle gjennom kroppen, den vissheten. Hun bare visste at det var sånn, og at ingen argumentasjon kunne få henne til å oppleve det annerledes [...] det griper ikke inn i livet mitt, tenkte Solveig". (Ørstavik, 2002, s. 150 ff)

Hanne Ørstaviks roman Uke 43 (2002) insisterer på at litteraturens sannhet ikke primært er kognitiv eller epistemologisk. Hovedpersonen, litteraturviteren Solveig, kjenner (u)sannheten som "en søyle gjennom kroppen", som å bli fysisk inntatt. Hos Ørstavik blir denne kroppslige erfaringen, ikke argumentet, en garanti for litteraturens ekthet og verdi, at den er forbundet med verden. Utover å gi assosiasjoner til kroppslige fenomener som seksualitet eller smerte (se for eksempel Frida Kahlos selvportretter) er Ørstaviks littercere bilde et forsøk på å si at litteratur og språk er sanselig og kroppslig. Romanen kan leses som et svar på hvordan kroppens betydning er blitt oversett i litteraturvitenskapen og den hegemonielle litteraturkritikken. ${ }^{1}$ 
På tross av den økende oppmerksomheten mot kroppen innenfor humaniora og motsvarende på opplevelsen i formidlingsteorien (for eksempel Balling, 2009), mangler systematiske perspektiver på formidling med kroppen som utgangspunkt. Dette kan betraktes som en side av at litteraturformidlingen "[s]om teoretisk felt er [...] at sammenligne med en donut: Samtidig med at der befinder sig en mængde relevante teoretiske perspektivet omkring emnet, er selve kernen tom, da der ikke er udviklet en egentlig teori for litteraturformidlingen" (Grøn, 2010, s. 26).

Mot denne bakgrunnen skisserer denne artikkelen et kroppslig basert formidlingsbegrep. Vår horisont er litteraturformidling, men fordi vårt begrep om formidling pretenderer å ha et bredere virkeområde henter vi også eksempler fra andre områder. Det teoretiske grunnlaget for dette arbeidet er Richard Shustermans fortolkning av Maurice Merleau-Ponty - i følge ham "the patron saint of the body" i vestlig filosofi (Shusterman, 2005, s. 151). Med utgangspunkt i Merleau-Pontys aksiom om at kroppens sanselighet både er noe annet enn det språket og bevisstheten kan representere, $o g$ en forutsetning for dem, etablerer Shusterman fire bevissthetsnivåer. For det første et umiddelbart og førbevisst som i søvnen, for det andre et intuitivt som når en fotballspiller treffer krysset uten å tenke på hvordan foten skal treffe, for det tredje et representerende som når fotballen oppfattes som ball og for det fjerde et metabevisst der en er seg bevisst sin egen bevissthet (2005, s. 156-158). Der Shustermans "levels" eller bevissthetsnivå signaliserer en hierarkisk lagdeling fra det sanselige til det kognitive, skiller vi heller mellom modi for å understreke at det handler om ulike måter å se og forstå på som griper gjensidig inn i hverandre. Med Shusterman som plattform, men med sideblikk til perspektiver fra andre tradisjoner, vil vi argumentere for en forståelse av formidling betinget av fire bevissthetsmodi som alle forholder seg til omgivelsene kroppen er involvert i: Fornemmelse, oppmerksomhet, artikulasjon og stemme.

Mot denne bakgrunnen forstår vi formidling som en romlig basert relasjonell aktivitet: en utveksling mellom kropper på flere nivåer som ikke kan tenkes i dikotomier (subjekt-objekt, språk-sanselighet). En konsekvens av denne tilnærmingen til formidlingsbegrepet er at perspektivet vårt kommer til å vandre mellom å betone den formidlende kroppen og den lyttende - avsenderen og mottakeren. Denne vand- ringen er en speiling av at vi dypest sett taler om den samme kroppen, de kroppslige betingelsene er ens. Enten det er "mottaker-" eller "avsenderkroppen" er begge situerte i omgivelsene. ${ }^{2}$ Når vi ikke anvender begrepene avsender og mottaker er det både fordi de konnoterer uavhengighet av hverandre og fordi formidlerens perspektiv flytter seg mellom å lytte til verket og å bli lyttet til. Formidleren er både avsender og mottaker.

\section{Fornemmelsen - begynnelsen}

Shustermans første nivå viser til at bevisstheten ikke oppfatter noe, enten fordi den er konsentrert om noe annet som når en er oppslukt av en bok og ikke hører trafikkstøyen, eller fordi den er "simply unconscious tout court as in deep, dreamless sleep" (2005, s. 157). Her betones det at kroppen tilhører omgivelsene på en altoppslukende måte som paradoksalt går forut for bevisstheten. Kroppen er verken oppmerksom på seg selv eller sine omgivelser. Dette første nivået kjennetegnes av ikke-bevissthet. Det skiller seg fra Shustermans andre, men også førspråklige nivå, ved at bevisstheten da er forbundet med noe i verden utenfor. På det første nivået er imidlertid kroppen ikke klar over at den oppfatter. Den er retningsløst viklet inn i omgivelsene. I denne tilstanden er ennå ikke noe skilt ut som forskjellig fra noe annet, subjektet er derfor verken klar over sin egen eller noe annets eksistens.

For teorien om formidling er dett første nivået primært interessant som formidlingens forutsetning: Dens begynnelse er at noe trer fram fra en bakgrunn og oppfattes. Når vi her bruker begrepet fornemmelse som et av formidlingens modi er det som en markør for den begynnende bevegelsen ut av dette nivået. Fornemmelsen viser til det kroppen aner uten å vite, den er en vegviser som peker ut av det forskjellsløse. For Drude von der Fehr representerer fornemmelsen "vår eneste direkte og umiddelbare forbindelse med en faktisk verden. Fornemmelse av kroppen er den eneste sammenfallende relasjonen vi kan være i. I alle andre relasjoner finnes en distanse [...] Problemet med fornemmelse er at den ikke kan kommuniseres som distanse" (Fehr, 2008 s. 74). I fornemmelsen forsvinner grensene mellom kroppen og omverden, og mellom refleksjon/språk og følelser/ affekter/sansninger. 
Hvor vanskelig denne transponeringen av fornemmelse til språk er, viser Balling i sin studie av leseopplevelser. Hun påpeker hvordan "informanternes udsagn er preget af en enkelhed, som synes at stå i modsætning til læsningens kompleksitet [...] som en banal italesættelse af læseoplevelsen, der foregår mer eller mindre ureflekteret" (2009, s. 136). Det banale defineres som en følelse der noe tas for gitt og en ureflektert anvender symboler og ritualer. ${ }^{3}$ Den manglende presisjonen i informantenes beskrivelser tolkes dels som at "den meningsdannelse og de følelser og de refleksioner, som opstår i forbindelse med læsningen, knap registreres av læseren, dels at italesættelsen af læseoplevelsen vanskeliggøres på grund af en manglende refleksion over læseoplevelsen som fænomen" (Balling, 2009 s. 137). Om man forstår det banale som en form for allmenngjøring eller alminneliggjøring av en kompleks opplevelse har Balling trolig rett, men denne alminneliggjøringen ser ut til å dukke opp i alle mulige sammenhenger der leseerfaringer skal språkliggjøres; jurybegrunnelser, aviskritikker, boktips eller som hos Balling intervjuer med lesere. I vårt perspektiv er det imidlertid ikke det banale som mangel, men som markør for en nødvendig forskjell som da kommer til syne: Forskjellen mellom den primære, kroppslige og førverbale modus og det som vedrører oppmerksomhet og artikulasjon. Om vi aksepterer at opplevelsen aldri kan nås fullt ut av språket slik premisset er hos Merleau-Ponty og Shusterman, så uttrykker banalitetene eller den språklige hjelpeløsheten en famlende bevegelse over en fornemmelse. Mangelen på språk, som den banale frasen tilkjennegir, kan da peke mot de stedene i litteraturen - eller i fotografiet som Roland Barthes er opptatt av - som griper oss, berører og som vi nettopp ikke helt forstår eller kan navngi Roland Barthes' punctum (1996a, s. 51). Det banale (frasen) uttrykker en famling over noe vi ikke vet hva er, men dermed også fornemmelsen av at det kan være noe der, noe i den litterære opplevelsen det er grunn til å arbeide videre med, som grunnlag for en formidlingspraksis, som motivasjon for å fortsette å lese en litteraturblogg eller lytte til stemmen som snakker om litteraturen.

Drude von der Fehr skriver at selv om fornemmelsen ikke er kunnskap, så "representerer [den] grunnlaget for en persepsjonsutvikling som i det lange løp kan føre til kunnskap [...] fornemmelsen og den direkte forbindelsen til kroppens liv kan [... ] utvikle en spontanitet og en kreativitet som kan virke utviden- de på vår oppfattelse av oss selv og verden" (Fehr, 2008 s. 74). Formidling handler om å være lydhør, ikke bare for verkets stemmer og det de både sier og ikke sier rett ut, men også for forsamlingens respons - taushetens tvetydighet. Fornemmelsen er således formidlingens motivasjon og begynnelse.

\section{Oppmerksomhet - synkronisering}

Som et av bevissthetens modi beveger fornemmelsen bevisstheten fra det forskjellsløse over i en modus hvor den er oppmerksom på noe, men uten at denne oppmerksomheten blir representert, uttalt eller får en utside. Et av Shustermans eksempler er at en kropp intuitivt tilpasser seg en døråpning uten å måtte tenke gjennom på forhånd om den er stor nok (Shusterman, 2005, s. 157). Shusterman karakteriserer denne andre bevissthetsmodus som "conscious perception without explicit awareness. In such cases, I am conscious and perceive something, but I do not perceive it as a distinct object of awareness and do not posit, thematize, or predicate it as an object of consciousness" (Shusterman 2005, s. 157).

Når leseren oppslukes av fiksjonen er oppmerksomheten konsentrert om å følge teksten i en art estetisk opplevelse som eksempelvis kan karakteriseres ved hjelp av termer som "moments-of-intensity", "presence-effects" eller fysisk berøring slik hans Ulrich Gumbrecht gjør (2004). Drude von der Fehr forklarer tilsvarende hvordan den gode litteraturen virker kroppslig, gjennom en forestilling om tro i betydningen fysiologisk forbindelse mellom kropp og bevissthet. Med Marianne Janacks og William James skriver hun at "når vi tror er vår bevissthet fylt helt av dette ene, og alt annet utelukkes. Tro kan altså beskrives som en følelse som fyller oss helt. Tro er en kroppslig reaksjon, en form for interaksjon mellom kroppen og verden [...]" (Janack, 2006 s.160-61; Fehr, 2008 s. 32). ${ }^{4}$ Trosbegrepet illustrerer hvordan Shustermans andre bevissthetsmodus innebærer en konsentrert oppmerksomhet i forbindelsen mellom subjekt og objekt.

Overført til formidlingsbegrepet handler dette om oppmerksomhet. Å oppfatte noe med oppmerksomhet forutsetter fortrolighet med omgivelsene enten de er materielle, sosiale eller tekstuelle. Å være oppmerksom er at bevisstheten er synkronisert mellom kroppen og noe - en tekst som leses, en formidling som følges, en tanke som tenkes. Psykologen Da- 
niel Stern beskriver hvordan mennesker i alminnelige hverdagsaktiviteter tilpasser seg hverandre på en umiddelbar måte som ikke er regulert av selvrefleksjon. De er ubevisst koordinerte - er synkronisert med tekster, rom, objekter eller hverandre uten å måtte gå veien om bevissthet og representasjon.

"For at kunne resonere med en eller anden må man ubevidst være synkroniseret med den pågældende person. Man kan bevæge sig synkront, som elskende gør, når de sidder ved et kaffebord og afbilder en dans, alt imens de på samme tid nærmer og fjerner deres ansigter fra hinanden eller søger hinandens hænder i samme øjeblik. Eller man kan koordinere hastigheden og ændringerne i sine bevægelser og derved skabe en slags dagligdags praktisk pas de deux sammen med en anden - du vasker for eksempel op, mens den anden tørrer af. Du rækker den våde, vaskede tallerken til den, der tørrer, i én jævn fælles bevægelse uden mellemliggende pauser [...] den udstrakte arm hos den person, der tørrer af, er perfekt tidsmæssigt koordineret med den udstrakte hånd hos den person, der overrækker tallerkenen". (Stern, 2005 s. 95 ff)

I forhold til hverandre eller sine omgivelser beveger subjektene/kroppene seg rytmisk og flytende, ikke stakkato og knuffende om det da ikke er underordnet en annen koreografi. De synkrone bevegelsene gjør oss oppmerksomme på forbindelsen mellom subjektet og objektet som et viktig aspekt ved formidlingen. Selv om synkroniseringen i utgangspunktet er kroppslig og ikke-verbal kan den også avleses i språklig kommunikasjon eller retorikk. Det alminnelige uttrykket "å snakke forbi hverandre" kan selvsagt henvise til rent semantiske forhold, men fra dagliglivet vet vi også at en tilhørers oppmerksomhet bestemmes av stemmens kvalitet, av opplevelsen av å bli snakket til, av å fornemme en tilstedeværelse.

Til sammen vil slike faktorer virke medbestemmende for hvorvidt det skapes en gjensidig oppmerksomhet $\mathrm{i}$ formidlingssituasjonen. Formidlingen avhenger av lydhørhet for verket, mot lytterne og de man taler til. Et fravær av oppmerksomhet viser seg i et intervju med Dag Solstad om hans roman Professor Andersens natt (1996). Dag Solstad blir spurt om hvorfor hovedpersonen ikke melder fra om mordet han tror han sett. Solstad svarer først med taushet, så med hoderystende bevegelser og en avvisende kommentar om at det er nettopp det romanen handler om (Bokbadet NRK 2007). Intervjuerens spørsmål og Solstads (kroppslige og verbale) respons viser at intervjueren (formidleren) ikke er synkronisert i forhold til den hun snakker med og dermed heller ikke til tilhørernes forventninger.

Enten vi har å gjøre med lesing av litterære tekster eller formidlingspraksiser kan vi si at oppmerksomhet aksentuerer selve forbindelsen dels som kontakt, dels som et uavklart spill av å gi og å ta, gripe og bli grepet, påvirke og påvirkes. Horace Engdahl reflekterer omring oppmerksomheten med forelegg i Johann Gottfried Herders Über den Ursprung der Sprache (1792) hvor han undersøker sjelens grunnleggende egenskap "Besonnenheit". Engdahl kommenterer at "Besonnenheit" vanligvis oversettes med refleksjon.

"...men av Herders beskrivning att döma är det en tankeform som har sin rot i uppmärksamheten [...] Vi kan inte föreställa oss uppmärksamheten som en neutral observasjon. Snarare fastnar min blick på nogonting, och det kan vara svårt att avgöra om jag ger eller tar emot mening, om jag upptäcker eller projicerar [...] Den er förtätad och ögonblicklig och den skickar min tanke i en ny riktning. I det jämngrå spelet framför mina ögon har någonting gjort tecken $[\ldots]$ Men i uppmärksamhetens ögonblick finns ännu inget bestämt subjekt att foga til nogot bestämt predikat, vilket omdömet förutsätter. Snarare har vi påträffat den zon ur vilken subjekt och objekt främträder och skiljs" (Engdahl, 1988 s. 8 ff).

Utover å karakterisere oppmerksomheten som et samspill av å projisere og å oppdage, kjennetegnes den i følge Engdahl av en spenning mellom det øyeblikkelige og det utstrakte. Oppmerksomheten er en sone der relasjonen mellom subjekt og objekt ikke er fastlagt. Oppmerksomheten fanges der og da, men i formidlingen må den også vedlikeholdes - tennes på nytt og på nytt i mer eller mindre tette intervaller. Tilhører-, seer- eller leserkroppen må holdes fast i situasjonen slik at hun ikke velger å gjøre noe annet. Oppmerksomhet innebærer en engasjert tilknytning som både tennes og tenner. Oppmerksomheten utvikler og konsentrerer fornemmelsen. Det gir bevisstheten retning og kraft. Når oppmerksomheten så sendes i en ny retning kan det være en forfølgende bevegelse innover i eller med formidlingen, men også en assosiasjon som fører ut av teksten. Dissosiasjon eller distraksjon kan bety å ikke være tilstede el- 
ler miste konsentrasjonen om det stemmen utsier noe om, men kan (eller vil) også bety at man er tilstede i assosiasjonen - $\mathrm{i}$ en egen tankerekke eller en erindring av et annet bilde - at man mentalt forflyttes over til et annet sted. ${ }^{5}$

\section{Artikulasjon - spørsmålstegnet}

Hvor de to foregående nivåene til Shusterman presiserer hva Merleau-Ponty betegner som det før-verbale, gjelder de to neste bevissthetens evne til representasjon, språk. På det tredje nivået er bevisstheten ikke bare klar over at, men også hva den oppfatter.

"[P]erception can also be raised to a third level in which we are consciously and explicitly aware of what we perceive. We observe the doorway as a distinct object of perception; we explicitly recognize that we are short of breath or that our fists are clinched. At this level, which Merleau-Ponty regards as the level of mental representations, we can already speak of what I call explicitly conscious somatic representations". (Shusterman, 2005 s. 158)

Shusterman klargjør den vesentlige overgangen mellom å være oppmerksom på noe (for eksempel en fornemmelse av det gode (kvalitet) i en passasje fra et litterært verk), og en stadig mer finmasket språklig innsirkling av det. Shustermans tredje nivå danner derfor grunnlaget for en bevissthetsmodus som framhever formidlingens forhold til språket som et instrument for oppdagelse eller artikulasjon av det som først fornemmes og så fanger oppmerksomheten: en analytisk beskrivelse henimot en klarere og mer presis representasjon.

Når vi her velger begrepet artikulasjon er det med henvisning til den latinske etymologien hvor articulatio betegner å skille (opprinnelig kjøttstykker) fra hverandre, og til måten man former lyder til forståelig tale: Artikulasjon er et arbeid for å forme lyder til ord og setninger som gir et så presist og dekkende bilde som mulig av det som oppfattes. Å artikulere er å se stadig klarere gjennom språket. Hans Jörg Rheinberger beskriver vitenskapelige eksperiment som å kaste ut et finmasket språklig nett (1997, s. 78). Tilsvarende er litteraturformidlingens tredje modus en språklig utforskning gjennom det vi kunne kalle artikulasjonens dynamikk - enten formidlingen er muntlig, skriftlig eller mediert gjennom andre "språk". Det vil si å beskrive slik at man også oppdager mer, stiller åpne spørsmål som ikke venter svar. Kanskje kan vi da beskrive artikulasjonens dynamikk som et spørsmålstegn mellom åpenhet og svar: Et slags ingenting rett før noe blir til, eller som at dette rett før eller ennå ikke framtrer som mer vesentlig enn det som følger etter og "egentlig er". Med Jean François Lyotard er forutsetningen for en slik dynamikk at det før spørsmålet finnes en åpenhet der spørsmålstegnet er satt inn mellom oppmerksomhet og artikulasjon - mellom at noe skjer, og hva som skjer. ${ }^{6}$

"At det sker går så at sige altid forud for det spørgsmål, der vedrører det, som sker. Eller det er snarere spørgsmålet, der går forud for sig selv. Thi 'at det sker' er spørgsmålet i dets egenskab af begivenhed, først 'dernæst' vedrører det den begivenhed, som netop er sket. Begivenheden sker som spørgsmålstegn, 'før' den sker som spørgen". (Lyotard, 1994 s. 49)

Lyotard utfordrer oss til å tenke på konjunksjonen at som en begivenhet i tiden det kan stilles et spørsmålstegn ved som igjen kan berede grunnen for å kunne artikulere: "to name, to lay the foundations for, the world" (Barthes, 1993b s. 26). ${ }^{7}$

Gjennom spørsmålstegnet forbindes artikulasjonen i en formidlende praksis også med gaven og generøsiteten. I et konvensjonelt antropologisk perspektiv er gaven innspunnet i en sosial økonomi av ytelse og gjenytelse. Utenfor bytteøkonomien forventer imidlertid ikke gaven et gjensvar. Løsrevet fra gjenytelsen manifesterer den en forståelse for den andre basert på spørsmålstegnet. Gaven er ikke da et svar på hvem den andre er, men på at han er. Spørsmålstegnet er derfor garantisten for at gaven som artikulasjonen forblir en hendelse som holdes åpen, at den som lytter uforpliktet kan ta i mot som en gave. Det minner oss om forutsetningen for det gamle bibliotekidealet: å finne den rette bok til den rette låner, "de bestræbelser, der udfoldes i biblioteket for at lede materialer og brugere sammen" (Thorhauge, 1989, s. 104). Uten spørsmålstegnet virkeliggjøres ikke idealet. Når bibliotekaren tilbyr leseren det han på forhånd vet, har han allerede svaret. Hva som er rett bok for akkurat denne leseren i akkurat dette øyeblikk kan han ikke vite på forhånd. Men med spørsmålstegnet forvandles idealer til bestrebelser, praksis. 
Formidling handler om å analysere kvalitetsperspektiv (mitt og ditt og dets) som realiserer lesemåter og lesestrategier, men alltid også om å ha spørsmålstegnet i sin midte. Det spørsmålstegnet, gaven og bibliotekidealet viser oss er biblioteket som et rom som tilhører en utlånsøkonomi som er åpen for og avhengig av samtalen (om litteraturen) på en helt annen måte enn en kjøp- og salgsøkonomi (Oterholm 2003, s. 10). "Kan hende burde en leite [...] etter metaforen for en slik utlånsøkonomi - i berøringa, blikkkontakten, og de ufrivillige nikkene med hodet som gir tilkjenne en anerkjennelse av samtalepartnerens tilstedeværelse og rett til å snakke" (Wahnsinn, 2003 s. 56). Møtet mellom formidler og formidlende eller verk og leser behøver det ikke-planlagte. Lyotards spørsmålstegn betegner en motkraft til på forhånd å vite best, og til kravet om å felle og argumentere logisk for estetiske dommer. I det vi kan lese som en forlengelse av åpenheten i Lyotards spørsmålstegn, spør Sissel Lie: "Hva med den forelskede lesningen som unngår å ta herredømme over teksten, men søker å oppdage alle dens krinkler og kroker? [...] forelsket åpenhet innebærer en mindre grad av forhåndsetablerte forventninger" (Lie, 1995 s. 193). Det handler om å ta seg tid, forsøke å unngå kravet om å finne en mening hvis teksten ikke vil etablere noen, men heller være oppmerksom på at dette kan romme noe annet: $\AA$ fornemme det som kan finnes i forholdet mellom det teksten sier og den pragmatiske situasjon leseren står i. Spørsmålet om sannhet forskyves (performativt, pragmatisk) fra hva noe betyr eller hvilke mulige meninger det har, til å bli et spørsmål om hva formidling er og gjør - hvordan formidlingen griper inn i livsverdener. Å artikulere verden er også å omforme den.

\section{Stemme - metafor}

Grensen mellom det tredje og det fjerde bevissthetsnivået til Shusterman går mellom at bevisstheten er klar over hva den oppfatter, og bevissthetens refleksjon over seg selv og sitt eget forhold til gjenstanden. Der Merleau-Ponty opererer med kun språklig representasjon, skiller Shusterman mellom eksplisitt interesse for et objekt og interesse for denne interessen. Shustermans fjerde nivå karakteriseres av at "we are not only conscious of what we perceive as an explicit object of awareness, but we are also conscious of this consciousness, and we focus on our awareness of the object of our awareness through its representation in our minds" (Shusterman, 2005 s. 158). Hvor skillet mellom oppmerksomhet og representasjon på den ene siden er problematisk, tydeliggjør det også overgangen fra artikulasjon til selvrefleksjon.

Den polske kunstneren Miroslaw Balkas How it is (2009-10) iscenesetter denne overgangen - dobbelheten. Verket er en stor container plassert i en turbinhall, helt svart, innvending kledd med sort fløyel. "'How shall I move forward?' you might ask yourself, as you stand at the threshold, confronted by the darkness ahead" (Tate Modern, 2009). ${ }^{8}$ I blinde entrer vi containeren via en rampe på den ene kortsiden. Verket (objektet) konstitueres av at vi (alle sammen) vandrer innover i mørket mot containerens endevegg. Vandringen skjer vekselvis i containerens midte og mer smygende langs de sorte fløyelsbelagte veggene. Vi famler oss fram. Vandringen gjør oss oppmerksomme både kroppslig og psykologisk: på mørket, på de andre tilskuerne som vi får et slags fellesskap med (vi vet ikke hva som skjer), på den egne bevegende kroppens usikre steg. Det er som om selve det kroppslige utgangspunktet for oppfatning og oppmerksomhet ble destabilisert. I forsøket på å artikulere det som skjer framstår selve relasjonen eller møtet mellom den egne kroppen, mørket, veggene, rommet og de andre kroppene som det egentlige verket. Dette kulminerer i det vi snur oss for å gå tilbake. Da ser vi containerens åpning som en billedramme omkring menneskelige silhuetter. I ett øyeblikk er vi (lettet) en tradisjonell kantiansk tilskuer som har gjenvunnet kontrollen og fremdeles famlende i det vi samtidig ser. I øyeblikket av lettelse over igjen å kunne orientere oss, aner vi det katalogteksten sier: "How it is only complete when you, the viewer enter". Likesom grunnlaget for persepsjonen blir også verden (verket) destabilisert. Balkas verk synliggjør og problematiserer forskjellen mellom en registrerende tilnærming til verden og å bli seg bevisst måten verden oppfattes på - overgangen fra artikulasjon til stemme.

For denne fjerde bevissthetsmodus der bevisstheten ikke bare bruker språket til å erkjenne eller oppdage, men derigjennom også blir oppmerksom på seg selv og sin egen måte å bli bevisst på, vil vi bruke begrepet stemme. Stemmen betegner den som taler i en direkte formidling mellom bibliotekar og låner, men er også en metafor for det som utsies og måten det utsies på. Stemmen er virkeliggjøringen av formidlingen: fornemmelsen, oppmerksomheten og den stadig mer finmaskete artikulasjonen. Den har både en 
fysisk, kroppslig komponent, og en semantisk betydningsbærende. Stemmen har en materiell framtoning som kan oppfattes avslappet eller intens, fraværende eller engasjert, og den formidler noe: ordene refererer (i visse omgivelser/en gitt kontekst) til et verk, et forfatterskap eller en særlig tematikk i samtiden. En kommentar i den norske avisen VG tydeliggjør hvordan tidligere president Bill Clinton ble lyttet til: "Jeg spaserer over Cross Campus, der president Clinton i oktober $2001^{9}$ snakket til 8000 mennesker, et sted i mylderet sto jeg og så ham på storskjerm. Han var magnetisk mens landet var ennå i sjokk over angrepet i september. Han sa oppmuntrende: "It's going to be all right". (Hjeltnes 2007) Clinton slipper unna med den største frasen av dem alle - hans retorikk hviler ikke på semantikken, men på at han gjennom ordene oppfattes som kroppslig til stede, ivaretagende og berørende hver enkelt.

Hvor bevisstheten i artikulasjonsmodus ser skarpt og nyansert gjennom ord og kategorier, pendler den i stemmen over mot å omforme dem til dekkende bilder, synteser eller metaforer for det som samlet sett er på spill sett i relasjonen til dem man snakker med - eller i forhold til verket. Om Tarjei Vesaas' erotiske Vårvinter (1968) sa en student at teksten (stemmen) vibrerer. I undervisningen, også en formidlingspraksis, vil lærerens oppgave da være å presisere og utvikle metaforen videre med grunnlag i en oppmerksom lesning av teksten og forholdet til studenten(e). I forhold til forfatterne som gir fra seg uferdige manus er forlagsredaktørene formidlere. En vesentlig side ved redaktørens kompetanse er å finne fram til dekkende metaforer for hvordan de opplever at forfatteren ut fra sine forutsetninger kan gjøre teksten så god som mulig (Oterholm og Skjerdingstad under utgivelse).

Formidlingens stemme synliggjør affiniteten med det som formidles: romanen, diktet eller skulpturen. Lydboken er for eksempel både et verk og en formidlingspraksis, opplesning og fortolkning. I en lydbokutgave av Hemingways $O g$ solen går sin gang (Hemingway \& Schau, 2007) fargelegger oppleserens stemmeleie og tonefall de kvinnelige karakterene som ynkelige og forminskede. I det som kan tenkes å være et forsøk på å skille mellom ulike stemmer i teksten gjøres kvinner nesten til barn, til stemmer uten ansvar. Hvorvidt dette speiler et mer eller mindre formodet kvinnesyn hos Hemingway, skal være usagt. Om formidlingens intensjon er å løfte det fram, så mislykkes det fordi stemmen som formidler overdøver verkets. Vi prøver å lytte oss fram til Hemingway, men den sterke betoningen gjør det vanskelig å høre. Fortolkningen og refleksjonen i stemmen skaper en støy som dekker over heller enn å løfte fram og tydeliggjøre Hemingways roman.

Samtidig som stemmen viser at formidlingen og verket henger sammen, skiller formidlingen seg fra verket ved å peke mot noe annet. Mens verket nok kan nære seg av for eksempel et engasjement for noe annet, vil formidlingen miste sin berettigelse uten linken til det som formidles. Formidlingen er ikke sitt eget mål, den skal peke mot en gjenstand. ${ }^{10}$ En bokpod formidler Helga Flatlands roman Bli hvis du kan. Reis hvis du må (2010). Poden er en kollasj av bilder som fader inn og ut først av et stort heldekkende øye så av forfatteren og manusark vi kan ane er fra et intervju med forfatteren. Noen bilder har undertekster som eksempelvis opplyser om at "Helga Flatland stjal kladdebøker på skolen og fylte dem med noveller og fortellinger" (Oppland fylkesbibliotek 2010). En voiceover leser fra boken og kommenterer $i$ en form som minner om en analyse av karakterer, komposisjon, miljø og tematikk. Stemmen oppleves patosfylt og alvorlig på en litt gammelmodig måte. I overgangssekvenser (som når man blar i en bok) omdannes forfatterportrettet og ligner (konnoterer) svevende papirfly. Papirflyene kan assosieres til krigen i Afghanistan som er romanens ramme, men uttrykkets art, retning og bevegelse gir ikke umiddelbar hjelp i den retning. Denotasjonen effekt $i$ en formidling forsvinner aldri. Poden kommer til å blafre fordi den ikke klarer å bestemme seg for hva den vil, fordi bruken av de tallrike virkemidlene virker tilfeldig og den lekne visuelle formen virker ustemt i forhold til hva ordene sier og hvordan. Iveren etter å skape et estetisk uttrykk i et nytt medium synes å undergrave formidlingen. Vi kan fornemme en intensjon, en samlet bevegelse som et forsøk på å rette seg mot unge, men samtidig aner vi en formidling som motarbeider den, som verken er oppmerksom på verket eller synkronisert med mottakerne.

Illustrerende kan vi sammenligne henvendelsen $\mathrm{i}$ denne bokpoden med den affekterte stemmen - den snakker i et toneleie som ikke virker synkronisert i forhold til det den snakker om. Et eksempel på en stemme som ikke er affektert, men heller faller sammen med og blir uatskillelig fra det den snakker om, kan vi se i en anmeldelse av Ingid Z. Aanestads 
roman Stormkyss. Under tittelen "Underlig underveldende" skriver Susanne Christensen i avisen Klassekampen (Christensen, 2010) en anmeldelse som er bortimot ugjennomtrengelig i formen. Samtidig viser en nærlesning en nærmest subtil synkronisering der boken liksom gjenskapes like mye gjennom anmeldelsens form som dens bokstavelige utsigelser. Problemet er imidlertid at det krever det nettopp en inngående nærlesning å få øye på. Anmeldelsen er nok oppmerksom på sin referanse, men knapt på avislesere uten høyere akademisk grad i litteraturvitenskap. Den som virkelig tar seg tid til å se anmeldelsen som en litterær gestaltning kan skimte boken, men den er sløret gjennom anmelderens performative og poserende gest. I motsetning til dette må formidlingen ikke bare peke på verket og si der og slik, men gjøre oppmerksom på forbindelseslinjene mellom det for eksempel romanen kan tilby og det den som ser, lytter eller leser, behøver, ønsker etc. Formidleren kan stå i veien for det som formidles, men selvsagt også være en døråpner.

Et arrangement om poesi og politikk ved Grünerløkka filial av Deichmanske bibliotek i Oslo (15. Juni 2011) problematiserer forholdet mellom de ulike stemmene og de muligheter som en formidlingspraksis har. Her skulle Ida Börjel (trodde vi) lese. Flere av oss fikk imidlertid utdelt en lapp der det stod: "Jeg har mistet stemmen: kan du hjelpe meg med å lese ved hjelp av en megafon". Poeten gikk deretter rundt og lot publikum lese tekster fra det som har blitt kalt en poetisk rekonstruksjon av "konsumentköplagens förlopp". ${ }^{11}$ Börjels formidling forskjøv imidlertid ikke bare forestillingen om en tradisjonell politisk poesi der budskapet har vært det sentrale og kommet i første rekke, men også forestillingen om det politiske. Gjennom publikums opplesning av "stemmer" som ikke var våre egne, ble begrepet ansvarlighet konkret og anskuelig. Å lese noe i megafon som man ikke var forberedt på og kanskje heller ikke var enig i, kjentes ubehagelig. Som publikum ble vi ansvarliggjort på en måte som den tradisjonelle politiske lyrikken (eller debatten) kanskje ikke hadde evnet. Samtidig skjøv dette også ansvarligheten i vår egen språkpraksis over på politikken. Vi havnet i et anstrengt forhold til et språk som ikke var vårt eget (noe politikere gjør hele tida?). Relasjonen mellom egen (u)ansvarlighet og politikkens (u)ansvarlighet kom til å krysse hverandre på en urovekkende måte. I denne settingen ble det med andre ord stilt spørsmål ikke bare om hva som ble sagt og hvordan, men også av hvem - eller av hva. Er det jeg som snakker, er det poeten, er det politikerne eller byråkraten eller politikken - er min stemme politikk? Rommer politikken min/din stemme? Vi kommer til å se politikeren snakke, men også usynlige tråder av ord og syntaks som synes å styre armene, bena, blikket, stemmen. Dessuten spørsmålet: Tier jeg? Snakker jeg? Hva sier jeg? Hvordan? Hvorfor ikke?

\section{Formidlingens omgivelser}

Börjels politiske formidlingspraksis får oss til å se politikerne som marionetter, men også våre egne stemmer som ekko i det (a)politiske rommet. Med Jacques Rancière forteller Börjel oss at litteraturformidlingens praksis innebærer å artikulere litteraturens evne til "[å] legge grunnlaget for politisk engasjement gjennom ei redistribuering eller rekonfigurering av det sanselege - forstått som heilskapen av den materielle verda i tid og rom der menneskeleg aktivitet spelar seg ut" (Kittang, 2009 s. 55). Börjels formidling etablerer et sted for forandring. Likesom litteraturen kan forstås som et erfaringsrom, kan formidlingen både peke på dette rommet og etablere seg som tilstøtende rom. Formidlingens oppgave er da å skape grunnlaget for et rom hvor en lytter eller leser kan slå seg til eller gå forbi. Kanskje kan formidlingen da forstås analogt med arkitektur. Arkitekten Christian Norberg-Schulz ser på arkitekturens oppgave som å skape et eksistensielt fotfeste som gjør det mulig å orientere seg videre.

"'Existential foothold' and 'dwelling' are synonyms; [...] 'dwelling', in an existential sense, is the purpose of architecture. Man dwells when he can orientate himself within and identify himself with an environment, or, in short, when he experiences the environment as meaningful. Dwelling therefore implies something more than 'shelter'. It implies that the spaces where life occurs are places, in the true sense of the word. A place is a space which has a distinct character. Since ancient times the genius loci, or 'spirit of place', has been recognized as the concrete reality man has to face and come to terms with in his daily life. Architecture means to visualize the genius loci, and the task of the architect is to create meaningful places, whereby he helps man to dwell". (Norberg-Schulz, 1980, s. 5) 
Om vi overfører Norberg-Schulz' argumentasjon til å gjelde formidling kommer vi endelig fram til et tentativt svar på formidlingens begrunnelse - en mulig konkretisering av det at som ligger til grunn for spørsmålstegnet. Ida Börjel og Jacques Rancière har begge et politisk prosjekt som satt på en enklest mulig formel handler om å se at verden kan se annerledes ut. Det Norberg-Schulz med Martin Heidegger minner om, er at for å kunne bruke nye måter å se på til å delta i samfunnsliv og politikk må man også ha en fornemmelse for hvor man er, for sine omgivelser. Norberg-Schultz poengterer at arkitekturen skal gi et fysisk vern som danner et rom det så er mulig å orientere seg videre ut fra. Overført til formidling ser vi da hvordan oppmerksomhet henger sammen med å kunne orientere seg og finne ut av noe også i figurlig forstand. Som metaforisk erfaringsrom blir formidlingen et sted som både er hjemlig og fremmed. Simultant med at lytteren forankres i hverdagen, forflyttes han til et annet sted. Dobbelheten av å forflytte seg til et fremmed (metaforisk) sted samtidig som en blir værende igjen i det velkjente: en dobbelteksponering av det som er og det som er mulig.

\section{Til sist}

Gitt at det er formidlingens oppgave å ivareta og videreføre aspekter ved verket som gjør det til hva det er, kan den forstås med utgangspunkt i kroppen og dens måte å forholde seg til omgivelsene på. Våre refleksjoner omkring formidlingens virksomme modi, i "donut"-begrepets tomrom for å bruke Grøns metafor, har hatt som mål å utvikle formidlingen som fagog forskningsfelt. Uavhengig av det mediespesifikke (muntlig, skriftlig eller multimedial) har vi argumentert for at formidlingen kan analyseres og sammenlignes på bakgrunn av fornemmelse, oppmerksomhet, artikulasjon og stemme foruten de omgivelser - det rom - kroppen behøver for å vite hvor den er.

\section{Noter}

1. For eksempler på denne devalueringen i litteraturvitenskapen og -kritikken se for eksempel Sontag, 1990 [1964]; Hagen, 2004; Gumbrecht, 2004; Littau, 2006; von der Fehr, 2008; Engelstad 2011. Allerede i 1964 etterlyste Susan Sontag en "erotics of art" på bakgrunn av det det hun så som abstraherende fortolkninger som fjernet seg fra litteraturen.
2. Merleau-Ponty grunngir et slikt syn i Phenomenology of Perception (2000).

3. Balling refererer her til begrepet banal nasjonalisme hentet fra Michael Billing i Gundelachs artikkel "Dansk identitet i en globaliseringstid" fra Dansk sociologi 1/2001.

4. Ballings begrep leseopplevelsen peker i same retning: "en helhedsoplevelse, hvori vi interagerer med verden omkring os og føler en tilfredsstillelse netop i kraft af, at alle vores evner bidrager til helheden" (Balling, 2009 s. 75).

5. Den overføringen som det å være tilstede på et annet sted innebærer, minner også om metaforen hvis funksjonsmåte rudimentært kan beskrives som nettopp en overføring av betydning mellom to felt. Metaforen innebærer en forflytning over i noe annet.

6. Det finnes en klar affinitet mellom oppmerksomheten og at noe skjer som hendelse - i begge fenomenene skjer noe før subjekt-objektrelasjonen er fastlagt. Begge kan opptre plutselig og uten forvarsel og relaterer slik til tiden og det performative: i en forstand iscenesettes overgangen mellom fornemmelse og artikulasjon.

7. I S/Z viser Barthes at tesen og antitesen er den pråklige figuren som garanterer for meningen. Tesen og antitesen navngir og opprettholder "the division between opposites and the very irreducibility of this division" (1993b, s. 65-66). I abstrakt form kan man karakterisere spørsmålsvarstrukturen med sine forventninger om et ja eller nei, som figurens urform. Et spørsmål krever også et svar (hvor irritert blir vi ikke når noen ikke svarer) og inngår slik i en økonomisk utveksling.

8. Balkas How it is har mange kilder og kontekster fra "the history of his native Poland" til Samuel Beckett's novelle How it is og Platons allegoriske hulelignelse.

9. At Bill Clinton er oppgitt som president i oktober 2001 endrer ikke poenget vårt.

10. Ulike estetiske praksiser innenfor ulike estetiske paradigmer vil selvsagt variere med hensyn til i 
hvilken grad de peker mot eller avviser at verket henviser til en virkelighet utenfor det selv. L'art pour l'art er kanskje det tydeligste eksempel på autonomiestetikk, realismen vil $i$ alle avskygninger avhenge av virkelighetsreferansen. Vårt poeng er at mens kunstverket kan ha nok med seg selv, har formidlingen alltid en forpliktelse på noe utenfor seg selv.

11. På bloggen til biblioteket ble Börjels Konsumentköpslagen: juris lyrik (2008, OEI editör) formidlet slik: Genom att plocka isär konsumentköplagen i dess språkliga beståndsdelar och därefter skapa en poetisk rekonstruktion av förloppet, lyckas Börjel frammana en tillspetsad men träffande bild av ett språkbruk (och därigenom en samtid) fullständigt genomsyrat av och oförmöget att relatera till individer annat än i konsumtionstermer. http://blogg.deichman.no/ folkebiblioteket/

\section{Referencer}

Balling, G (2009). Littercer cestetisk oplevelse: loesning, laeseoplevelser og loeseundersøgelser: en diskussion af teoretiske og metodiske tilgange. København: Danmarks Biblioteksskole.

Barthes, R (1993a). Camera Lucida. London: Vintage

Barthes, R (1993b). S/Z. Oxford: Basil Blackwell.

Bjorvand H, \& Lindeman F O (2007). Våre arveord: Etymologisk ordbok. Oslo: Novus

Bokbadet NRK (2007, 16. april). Hentet fra http://www.youtube.com/watch?v=remnOcZ1Ak8.

Bokmålsordboka (2001). Oslo: Dokumentasjonsprosjektet.

Christensen, S (2010). Underlig underveldende. Anmeldelse av Ingid Z. Aanestad: Stormkyss. I:Klassekampen 13. november 2010

Egeberg O, \& Skjerdingstad KI (2011). Tanken sitter $i$ øyet. Oslo: Novus

Engdahl, H (1988). Om uppmärksamheten. Lund: Tegnérsamfundet.
Engelstad, I (2011). "Så de store følelsers tid er vendt tilbake!" - Demokrati og melodrama i Bjørnstjerne Bjørnsons romandiktning. Norsk Litteraturvitenskapelig Tidsskrift, 01, 61-67.

Fehr, D von der (2008). Når kroppen tenker. Oslo: Universitetsforlaget.

Fioretos, A (1991). Det kritiska ögonblicket: Hölderlin, Benjamin, Celan. Stockholm: Norstedts.

Gripsrud, J (1990). Genrer, læsere og kvalitet. Om tekst- og smagshierarkier. MedieKultur. Journal of media and communication research, 6(14).

Gripsrud, J (2007). Mediekultur, mediesamfunn. Oslo: Universitetsforlaget.

Grøn, R (2010). Oplevelsens rammer. Former og rationaler $i$ den aktuelle formidling af skønlitteratur for voksne på danske folkebiblioteker. Aalborg: Det Informationsvidenskabelige Akademi.

Gumbrecht, H (2004). Production of presence: what meaning cannot convey. Stanford (Calif.): Stanford University Press.

Hagen, EB (2004). Litteraturkritikk: en introduksjon. Oslo: Universitetsforlaget

Hemingway, E, \& Schau, F (2007). Og solen går sin gang. Melhus: Lydbokforlaget

Hjeltnes G (2007, 2. juli). Bills hete omfavnelse. VG. Hentet fra http://www.vg.no/nyheter/meninger/artikkel.php?artid=171128.

Jakobson, R (1960). Closing Statements: Linguistics and Poetics. I T. A. Sebeok (Red), Style In Language. Cambridge (Massachusetts): MIT Press

Janack, M (2004). Changing the epistemological and psychological subject. I: R. Shusterman (Red.) The range of pragmatism and the limits of philosophy. Malden: Blackwell

Kittang, A (2009). Diktekunstens relasjonar: estetikk, kultur, politikk. Oslo: Gyldendal. 
Lie, S (1995). Hun skriver som en mann! I L. Nysted \& S. Lie (red.), Samtale med et svin: en antologi om litteraturkritikk. Oslo: Cappelen.

Littau, K (2006). Theories of reading: books, bodies, and bibliomania. Cambridge: Polity.

Lyotard, F (1994). Om det sublime Viborg: Akademisk forlag.

Merleau-Ponty, M (2000). Phenomenology of perception. London: Routledge.

Opplandfylkeskommune (2010). Hentet 4. juni 2012 http://www.youtube.com/watch?v=FxP7bNNEFBs

Oterholm, K (2003). Opp fra kjellerdypet. Forfatteren. (3), s. 7-11

Oterholm, K, \& Skjerdingstad, KI (under utgivelse). Med blikk for kvalitet. I Smidt J. K. Litteratursosiologiske perspektiver. Oslo: Universitetsforlaget

Rheinberger, H-J (1997). Towards a History of Epistemic Things. Synthesizing Proteins in the Test Tube. Stanford (Calif.): Stanford University Press.

Shusterman, R (2005). The Silent Limping Body of Philosophy. I: T. Carman \& M. B. N. Hansen (Red.), The Cambridge companion to Merleau-Ponty. Cambridge: Cambridge University Press.
Skjerdingstad, KI (2011). Det fenomenologiske blikket - et materialistisk perspektiv. I: R. Audunson (red.), Krysspeilinger. Oslo: ABM-media

Sontag, S (1990). Against interpretation: and other essays. New York: Picador.

Stern, DN (2004). Det nuvcerende øjeblik i psykoterapi og hverdagsliv. København: Hans Reitzel.

Tate Modern (2009). How it is. The Unilever Series: Miroslaw Balka. Hentet fra http://www2.tate.org.uk/ miroslawbalka/

Thorhauge, J (1989). Luk op for skønliteraturen. I: E. Munch-Petersen (red.), Litteratursociologi: en antologi (s. 102-111). Ballerup: Bibliotekcentralen.

Wahnsinn, S (2003). Passasjer fra det 20. århundret eller hyllemarkeringer til et antireproduksjonsalderbibliotek. Vinduet, (1)

Youtube (2010. 7. juli). Oppland fylkesbibliotek presenterer Helga Flatland. Hentet fra http://www.youtube.com/watch?v=FxP7bNNEFBs

Ørstavik, H (2002). Uke 43: roman. Oslo: Aschehoug. 